\title{
PROTOCOL FOR PERFORMING NEPHROLOGICAL ACTIVITY IN THE REPUBLIC OF MACEDONIA
}

\author{
Momir Polenakovic ${ }^{1,2}$, Stevka Bogdanovska ${ }^{1}$, Koco Cakalaroski ${ }^{1}$, Sonja Dzikova ${ }^{1}$, \\ Gjorgji Masin $^{1}$, Jelka Masin-Spasovska ${ }^{1}$, Angel Oncevski ${ }^{1}$, Vesna Gerasimovska ${ }^{1}$, \\ Goce Spasovski $^{1}$, Risto Grozdanovski ${ }^{1}$, Olivera Stojceva-Taneva ${ }^{1}$, Ladislava Grcevska ${ }^{1}$, \\ Aleksandar Sikole ${ }^{1}$, Petar Dejanov ${ }^{1}$, Liljana Tozija ${ }^{1}$, Katica Zafirovska ${ }^{1}$, \\ Ninoslav Ivanovski ${ }^{1}$, Ljubica Lozance ${ }^{1}$, Vladimir Pusevski ${ }^{1}$ \\ ${ }^{1}$ Department of Nephrology, Medical Faculty, Skopje, University of Ss. Cyril and Methodius, Skopje, \\ R. Macedonia \\ ${ }^{2}$ Macedonian Academy of Sciences and Arts, Skopje, R. Macedonia
}

Corresponding Author: Polenakovic Momir, Macedonian Academy of Sciences and Arts, Bul. Krste Misirkov br. 2, 1000 Skopje, R. Macedonia; Tel: + 389 (0)2 32354 00, Fax: + 389 (0)2 32355 00, E-mail: maknefpo@t-home.mk

\begin{abstract}
The fast development of nephrology in the world, especially in the second half of the $20^{\text {th }}$ century demanded protocol (guidelines) for nephrological activity for all levels of medical care, of doctors and specialists. The International Society of Nephrology, the European Renal Association and other national associations created their own protocol (guidelines) for nephrological activity. The Macedonian Society of Nephrology, Dialysis, Transplantation and Artificial Organs (MSNDTAO) proclaimed the First Protocol for Performing Nephrological Activity in the Republic of Macedonia at the First Congress of the MSNDTAO, held in Ohrid 1993, and it was published in the Macedonian Medical Review, 1994; Supplement 14: 397-406 [1]. The update of the Protocol for Performing Nephrological Activity in the Republic of Macedonia was proclaimed at the Fourth Congress of MSNDTAO, held in Ohrid 2012 and it presented in this text.
\end{abstract}

Key words: nephrological protocol, guidelines, national society, Macedonian Society of Nephrology, Dialysis, Transplantation and Artificial Organs (MSNDTAO)

\section{Introduction}

Nephrology had a fast development in the second half of the $20^{\text {th }}$ century.

The discovery and application of peritoneal and hemo-dialysis, renal transplantation, and application of renal biopsy and investigation of the tissue obtained by morphological methods (light microscopy, immune fluorescent and electron microscopy) contributed a lot to the fast development of nephrology in the world.

The International Society of Nephrology was established in 1960. Afterwards, several country i.e. national associations have been established at all continents. The rapid deve- lopment of the treatment of the end stage renal disease with artificial kidney and renal transplantation, as well as the better understanding of the morphology and physiology of kidneys, demanded an improved approach in the early diagnosis, treatment and prevention of kidney disease.

In the meantime, in the nephrology associations around the world guidelines for treatment of kidney disease have been created in order to help the doctors at all levels of medical care of kidney patients to improve early diagnosis, treatment and prevention of kidney disease. We will mention some of the guidelines: KDIGO Clinical Practice Guidelines 
(KIDNEY DISEASE | IMPROVING GLOBAL OUTCOMES) of the ISN; the European Renal Best Practice (ERBP) Guidelines of the ERA-EDTA; the Kidney Disease Outcomes Quality Initiative (KDOQI) of the National Kidney Foundation.

In the Republic of Macedonia, the Department of Nephrology at the Medical Faculty of the University of Skopje has been established in 1975, being as first separated Department from Internal medicine in former Yugoslavia. Hence, the doctors from the Department of Nephrology created the First Protocol for Performing Nephrological Activity in the Republic of Macedonia proclaimed at the First Congress of the Macedonian Society of Nephrology, Dialysis, Transplantation and Artificial Organs (MSNDTAO), held in Ohrid 1993,

\author{
Work group: \\ Manager: Acad. Prof. Dr. M. Polenakovic \\ Members (alphabetically): \\ Prof. Dr. S. Bogdanovska \\ Prof. Dr. K. Cakalaroski \\ Prof. Dr. S. Dzikova \\ Ass. Prof. Dr. V. Gerasimovska \\ Prof. Dr. R. Grozdanovski \\ Prof. Dr. L. Grcevska \\ Ass. Prof. Dr. P. Dejanov \\ Prof. Dr. K. Zafirovska \\ Prof. Dr. N. Ivanovski
}

Care for nephrologic patients in the Republic of Macedonia should be based upon the known and accepted principles in diagnostics and therapy. These principles should provide efficacy and rationality as basic premises of this protocol. Of special interest is the notion that the following doctrinal presumptions should be accepted:

- Implementation of doctrinal stance targetting prevention and early discovery of kidney diseases;

- Implementation of doctrinal stance for early treatment;

- Implementation of doctrinal stance for slowing the progression of kidney diseases;

- Implementation of doctrinal stance for renal replacement therapy with haemodialysis and transplantation. and published in the Macedonian Medical Review, 1994; Supplement 14: 397-406 [1].

During the Fourth Congress of MSNDTAO, held in Ohrid 2012, an update of the Protocol for Performing Nephrological Activity in the Republic of Macedonia was proclaimed. In the period between the First and the Second Protocol, the nephrological care in the Republic of Macedonia was substantially improved. Modern nephrology diagnostic methods were implemented, more than 1.400 patients undergoing dialysis and regular kidney transplantations were performed, being necessary that the doctors at all levels and specialties in the Republic of Macedonia be provided with an updated and modern Protocol for nephrological activity.

Ass. Prof. Dr. Lj. Lozance

Prof. Dr. Gj. Masin

Ass. Prof. Dr. J. Masin-Spasovska

Prof. D-. A. Oncevski

Prof. Dr. G. Spasovski

Prof. Dr. O. Stojceva-Taneva

Prof. Dr. A. Sikole

Ass. Prof. Dr. L. Tozija

Translations: Ass. Dr. V. Pusevski

The University Nephrology Clinic as the supreme institution in the Republic of Macedonia has the obligation to implement the newest and the most rational diagnostic and therapeutic measures. It should be a part of the educational system which should transfer modern knowledge and methods from various areas of nephrology to the entire health network in the republic.

The University Nephrology Clinic should also be part of the control of nephrologic activity in the country.

\section{BASIC NEPHROLOGY}

\section{a) General notion}

In this part of the nephrological activity procedures of various levels of health care in 
the diagnostics and therapy of nephrologic patients will be presented.

\section{b) Primary health care}

1. A complete medical examination is made and anamnestic data is taken and all positive and negative results are noted in the medical documentation.

2. Performs routine laboratory controls - urine, blood count, haematocrit, glycaemia, urine culture, part of lipid status, urea, creatinine, EKG (electrocardiograph).

\section{c) Secondary health care - internists}

In hospital conditions diuresis is followed, and if necessary performus the following laboratory tests:

- $24 \mathrm{~h}$ creatinine clearance, if necessary urea clearance;

- IV (intravenouse) pyelography and infusion pyelography;

- Routine ultrasound of the urinary tract;

- Inserts urinary catheter if necessary;

- Performs maximal concentration test;

- Performs dilutional kidney capacity test;

- Addis count for quantitative erythrocyturia and leukocyturia;

- Proteinuria by Eschbach, i.e. quantitative, semi-quantitative and qualitative;

- Test for determining the origin of haematuria;

- Test for detection of ortostatic proteinuria;

- PSP (phenolsulfonphthalein test) test for tubular secretion.

\section{d) Tertiary health care - University} Nephrology Clinic

In the University Nephrology Clinic the following tests and procedures are performed:

- Initial patient assessment;

- Further patient assessment;

- Renal biopsy;

- Direct immunofluorescent assessment of renal tissue;

- Biopsy with direct immunofluorescent assessment of other tissues (skin, muscle, gut);

- Detection of antinuclear antibodies with indirect immunofluorescent method;

- Detection of anticytoplasmatic antibodies with indirect immunofluorescent method;

- FA test (fluorescent antibody test for infection) with direct immunofluorescent method;

- Test for dysmorphic erythrocytes;

- Direct peroxidasis, detection of immune cells in kidney tissue;
- Tests for detection of lymphocyte subpopulations;

- Continual parenteral alimentation;

- Implementation of up-to date dialysis therapy;

- Testing haemodialysis membranes;

- Testing membrane biocompatibility;

- Initiation of erytropoetin in treatment of anaemia in patients on chronic hemodialysis programme;

- Assessment of renal osteodystrophy, therapy, and making decision for eventual parathyroidectomy;

- Transluminal angioplasty of AV fistula under monitor;

- Assessment of the function of the vascular access using the Doppler method;

- Ambulatory blood pressure monitoring;

- Assessment of curability of renovascular hypertension;

- Tests for assessment of tubular glucose threshold and maximum test for glucose;

- Test for proximal tubular renal function;

- Test for distal tubular balance of sodium, potassium and osmotic substances;

- PRA (Panel Reactive Antibody) / sodium, potassium, aldosteron index;

- Renal prostaglandin index;

- Saralazine test;

- Clinical testing of medicines (medicament);

- Regional data basis for nephrological conditions;

- Mucosa and bladder biopsy;

- Blood vessel, muscle and skin biopsy;

- Interventional ultrasound;

- Ultrasound-enhanced tissue biopsy;

- Ultrasound-enhanced renal cyst puncture and sclerosation;

- Ultrasound-assisted anterograde urography;

- Ultrasound-guided insertion of nephrostomy;

- Ultrasound-guided prostate biopsy;

- Ultrasound assessment of prostate volume and mass;

- Ultrasound assessment of rest urine;

- Performing renal transplantation;

- Initiation of immunosuppressive medications in treatment of renal diseases, and in kidney transplantation.

\section{IMMUNOPATHOLOGY AND SYSTEMIC DISEASES - PRIMARY AND SECONDARY GLOMERULOPATHIES}

\section{a) General notion}

In this part all diagnostic and therapeutic measures for treatment of patients with primary 
and secondary glomerulopathies will be mentioned.

\section{b) Primary health care}

When glomerulopathy or other immunemediated renal or system disease with renal affection is suspected, the following data and laboratory analyses should be performed:

- Urine, qualitative proteinuria;

- Sedimentation with blood count;

- Degradation product (urea, creatinine);

- Glycaemia, lipids, total, and cholesterol;

- Information about hypertension and diuresis.

c) Secondary health care - internists

1) When immune-mediated disease is suspected, $24 \mathrm{~h}$ semi-quantitative or quantitative proteinuria, erytruria from urine sediment with quantitative erytruria, ultrasound and further referral for differentiation and clinical assessment.

2) Obligatory follow-up of patients following recommendations from the University Clinic and referral for clinical examination as prescribed by clinician.

3) Should not alter the specific therapy except when side-effects require immediate termination or confirmed interreaction with another medicine or condition. Cases where termination of that therapy has led to worsening will be discussed separately with teams from the clinic and secondary service.

\section{d) Tertiary health care - University Nephrology Clinic}

The University Nephrology Clinic performs the following diagnostic and therapeutic measures:

1) Histological diagnosis of primary or seconddary immune mediated nephropathy by renal biopsy.

2) Assessment of the activity of the immune process by measuring:

- Serum concentrations of complement, immunoglobulins, circulating immune complex, etc.;

- Identifying antinuclear and anticytoplasma antibodies;

- Performing skin biopsy.

3) Initiation of specific immunosuppressive therapy (steroids, cytostatic drugs, non-steroidal antinflammatory drugs, cyclosporin and plasmapheresis).
4) Polyclinical control of the diagnosed patients with regard to condition, correction of therapy if necessary. Certain controls can be performed in secondary health care (blood pressure variations, kidney function variations and blood count as a consequence of therapy). If necessary these are referred to the clinic.

5) Managing complications of the therapy.

\section{TUBULOPATHY}

\section{a) General notion}

Congenital tubulopathies are discussed in paediatry. Here, methods for treatment of acquired tubulopathies and/or those presented as clinical syndromes will be discussed.

\section{b) Primary health care}

- Analyzing clinical and laboratory findings which can suggest tubular damage (see urinary syndrome), change in the acidic capability of the kidneys.

c) Secondary health care - internists

- Semiquantitive and/or quantitive analysis of the proteinuria and glycosuria, and possible toxic factors;

- Patient follow-up.

\section{d) Tertiary health care - University Nephrology Clinic}

- Follow-up of tubular function;

- Functional examination of the kidney;

- Histological conformation.

\section{OBSTRUCTIVE NEPHROPATHY}

\section{a) General notion}

In this part, patients and the obstructive moments will be taken care of in collaboration with the urologists.

\section{b) Primary health care}

- Making assumptions based on clinical signs and routine laboratory findings (see urinary syndrome).

\section{c) Secondary health care - internists}

Perform some differential tests for detection of the obstruction:

- Ultrasound;

- Plain RTG and intravenous pyelography; 
- Other imaging methods.

\section{d) Tertiary health care - University Nephrology Clinic}

- The level of obstruction is determined and if necessary the patients is treated by urologists;

- Obstruction/renal failure ratio is analysed.

\section{CONGENITAL ANOMALIES AND HEREDITARY DISEASES}

\section{a) General notion}

In this part the methods for early detection and prevention, as well as therapy of certain hereditary kidney diseases and congenital anomalies will be discussed.

\section{b) Primary health care}

- When suspected of renal disease, referral to internists;

- In patients with a familial burden of certain anomalies even when a minimal result is found, clinical or laboratory, referral to internist;

- When familial burden of congenital anomalies is present, obligatory referral for screening.

\section{c) Secondary health care - internists}

The following is performed:

- Confirmation of the congenital anomaly with ultrasound and intravenous pyelography;

- Assessment of the kidney function;

- Assessment of present complication (infection, lithiasis);

- Control of the kidney function, follow-up of the infection.

\section{d) Tertiary health care - University Nephrology Clinic}

In clinical conditions, the following is performed:

- Detailed definition on the kind of congenital anomaly or familial disease through various tests (retrograde pyelography, CT scan and ultrasound) etc.;

- Assessment of possible or present complications (renal failure, infection);

- Assessing the possibility of correction - team work;

- Controls for preventing complication;

- Genetic tests.

\section{METABOLIC DISEASES}

\section{General notion}

This part is focused on the primary or secondary affection of the kidney in metabolic diseases.

\section{Primary health care}

- In patients with a metabolic disease in which renal involvement is possible (diabetes, primary hyperuricaemia) basic clinical and laboratory tests for determining the kidney function.

\section{Secondary health care - internists}

- Confirmation of presence of renal affection in metabolic disease through:

- Quantitative measurement of proteinuria, microalbuminuria;

- Frequent measurement of blood pressure;

- Determining serum urea and creatinine;

- Determining other laboratory findings;

- Ultrasound.

- Control of the basic condition to the proposed level of this kind of care for that condition;

- Polyclinic control of the patients and referral to appropriate facility;

- Following the prescribed therapy based on the clinical guidelines;

- Control of the fundus oculi and further clinical referral when change is found.

\section{Tertiary health care - University} Nephrology Clinic

- Assesses functional abnormalities in patients with metabolic disease;

- When necessary, gives histological diagnosis of renal failure, especially when there is a possibility of two separate conditions: metabolic and nephrologic;

- Consulting with other subspecialists, determines optimal therapy of the primary condition, points out which drugs can be used, nephrotoxical, drug interreactions, etc.;

- Periodically controls diagnosed patients.

\section{URINARY TRACT INFECTIONS \\ 1. General notion}

In this part methods concerning urinary tract infections which are not connected with other structural anomalies of the urinary system will be discussed.

\section{Primary health care}


When urinary infection is suspected, the general practitioner is obliged to confirm:

- Is it the first or second infection in that year, i.e. it is acute. If acute, the following is necessary:

- Urine, urine culture, and prescription of therapy based on antibiogram when significant bacteriuria is found (over 100000 live bacteria in $1 \mathrm{ml}$ urine, except for symptomatic bacteriuria over 20000 , chlamydia over 20-40 000, pseudomonas over 20000 );

- If acute and there is suspicion of acute pyelonephritis, the following is necessary:

- Referral to internist when positive urine culture and positive urine sediment are noted, symptoms of parenchymal infection, local symptoms and signs are present;

- When urinary infection is present for the third time, regardless of its location, referral to internist;

The following are not allowed:

- Catheterization or other manipulations in the urinary system in primary health care;

- Treatment without evidence for positive, i.e. significant, bacteriuria.

- The first therapy is uroantiseptics, unless contraindicated. For acute infection (distal urinary infection) 7-10 days is sufficient, 14 days after cessation of the therapy control a urine culture is taken, and if sterile, the next control is performed when necessary (new attack) or obligatory after 1 year when the following is tested:

- Urine;

- Urine culture if indicated.

- Acute distal urinary infection is not treated with parenteral therapy, except where oral therapy is contraindicated;

- The general practitioner should educate patients about mid-stream urine sample and genital cleaning prior to giving sample. He also treats recurrent urinary infection. After 7 days of unsuccessful therapy, he refers the patient to the internist.

\section{Secondary health care - internist}

- If an infection recurs more than twice a year, its location must be determined by:

- Ultrasound;

- Referring to UNC (University Nephrologic clinic) for FA test or performing Farley test in hospital with endoscopic department;
- The infection, as in primary health care, is confirmed by significant bacteriuria, urine analysis, and intravenous pyelography;

- Therapy is based on antibiogram. A sevenday treatment is started, on the seventh day a urine culture is taken, and the therapy is continued until the results are received. A sterile finding is an indication for cessation of therapy. Parenteral therapy is indicated for acute pyelonephritis for 14 days, after that per os therapy for 7-14 days. Urine control for both chronic and acute infections is performed 14 days after cessation of the therapy;

- Significant bacteriuria 14 days after cessation of the therapy (both chronic and acute infection) is an indication for hospital treatment;

- Chronic complicated infection confirmed by internist (infection with lithyasis, a stop in the urodynamics from any cause, patient with diabetes, analgetic nephropathy, during pregnancy and in patients with reduced global renal function, as well as patients with a single kidney) is an indication for hospital treatment.

\section{Tertiary health care - University Nephrology Clinic}

- The clinic treats every complicated urinary infection and every chronic infection that requires hospital treatment. It controls the patients at certain intervals, determines principles for follow-up and treatment which are later accepted by internists regarding laboratory and other diagnostic methods and therapy.

\section{ARTERIAL HYPERTENSION}

\section{a) General notion}

In this part we will elaborate arterial hypertension as a global problem by demonstrating the diagnostic and therapeutic methods at all levels of health care.

\section{b) Primary health care}

The following methods are obligatory:

- Obligatory measurement of blood pressure of every patient regardless of the cause of visit. When normal blood pressure is registered it must be noted in the patient's documentation and the next control must be appointed in one year (if necessary, earlier);

- Verification of hypertension is necessary before diagnostic and therapeutic measures are 
started, except in the case of already confirmed hypertension. Hypertension is verified if it is proven in three measurements over a period of 7 days;

- After verification, tests from the WHO (World Health Organization) microprogramme are conducted: urine, blood count with haematocrit, glycaemia, blood urea and creatinine, uric acid, total lipids and cholesterol, potassium, eye examination and ECG;

- Starting therapy with Ia (diuretic) or Ib (beta blocker) degree of the multiphase approach, and control after 4 weeks. After this period, the therapy is modified if necessary, with or without a new drug;

- Initiation of second degree multiphase approach after 4 weeks or increase of the doses of drugs. Second degree includes Ia plus Ib (diuretic plus beta blocker);

- In the case of failure of the former degrees, or suspicion of secondary hypertension, every diastolic hypertension above $90 \mathrm{mmHg}$, every patient with hypertension younger than 30 years, patients with signs of target organ damage, are an indication for referral to internists;

- Conducting complete history for every newly-discovered patient and following the protocol from the clinic.

\section{c) Secondary health care - internists}

The following methods are mentioned:

- Actively searching for secondary hypertension with an expanded programme including detailed anamnesis and status, intravenous pyelography, ultrasound of the urinary system and abdominal organs, ECG with modalities, laboratory tests at secondary care level determined for diagnosing hypertension according to the protocol;

- Implementation of the second and third degrees of multiphase therapy (diuretic, plus beta blocker, plus dilatators with/or $\mathrm{Ca}$ antagonists), after prior confirmation of the failure of Ia and Ib degrees;

- Referring patients with symptoms, tests and laboratory data to the expanded programme for testing secondary curable and incurable hypertension. This concerns patients with severe manifested target organ damage and possible complications;

- Referral for clinical assessment of hypertension associated with other diseases which may affect its course or vice versa and require an individual approach in the therapy;

- Referral for control and follow-up in the clinic for malignant hypertension, refractory hypertension and for third degree of multiphase approach;

- Individual approach in complicated patients.

\section{d) Tertiary health care - University Nephrology Clinic}

The University Nephrology Clinic conducts the following:

- Assessment of complicated, refractory, malignant, visceral hypertension, as well as hypertension crisis;

- Application of therapeutical approach and transfer of knowledge in the area of diagnostics and therapy;

- Assessment and treatment of secondary curable and incurable hypertension after prior confirmation from the secondary health care;

- Implementation of the fourth degree of the multiphase approach in the therapy (previous drugs plus ACE (angiotensin - converting enzyme inhibitor) inhibitors + ARB (angiotensin receptor blocker);

- Continuous education and supervision of conducting protocol in diagnosing and treatment of hypertension;

- The clinic approves and initiates the formation of regional dispensers - centres or other forms of medical organization in charge of detection, partial evaluation, therapy, as well as making records of hypertensive patients;

- Forming a central data-base;

- Accepting pregnancy-induced hypertension discovered in secondary health care.

\section{PREGNANCY AND RENAL DISEASES}

\section{a) General notion}

In this part certain conditions which appear during pregnancy or have a causative connection with pregnancy are discussed. Because of their severity these are treated by internists or nephrologists.

\section{A. PREGNANCY AND URINARY INFECTIONS}

\section{a) Primary health care}

- Symptoms of urinary infections, distal or proximal, with or without fever, temperature or lumbar pain are indicative for taking a blood 
count and urine analysis, and immediate referral to internists.

\section{b) Secondary health care - internist}

At this level the following is conducted:

- Treatment of distal urinary infection with present symptoms and signs, with positive urinary findings (RBC and WBC), and significant bacteriuria. Treatment begins with one of the drugs allowed during pregnancy, and later it can be changed with regard to the results of the antibiogram which is taken before the start of treatment. This therapy is conducted orally (if possible);

- Controls patients with distal urinary infection by taking a control urine culture 14 days after the treatment has stopped. If significant bacteriuria is present, therapy is conducted regardless of whether there are symptoms or not. If the urine culture is sterile after 14 days, controls are performed once a month. More than two distal infections are an indication for consultation with a nephrologist;

- Proximal urinary infection (acute pyelonephritis as well as exacerbated chronic pyelonephritis) is treated by the nephrologist.

\section{c) Tertiary health care - University Nephrology Clinic}

The University Nephrology Clinic performs the following:

- Controls, diagnoses, and treats pregnant patients with a urinary infection following fever, i.e. acute and chronic exacerbated interstiopyelonephritis (IPN);

- Controls, diagnoses, and treats pregnant patients with more than two distal urinary infections (recidivated or relapsed);

- Patients with a known pre-existing condition which predisposes to infection or preexisting IPN are controlled in the University Nephrology Clinic. Predisposing conditions are: lithyasis, a stop in the urodynamics;

- Prescribes chronic use of uroantiseptics; and

- antibiotics.

\section{B. PREGNANCY AND RENAL FUNCTION}

\section{a) Primary health care}

- Any suspicion of renal function deterioration in pregnant patients is an indication for referral to internists;
- Preexisting renal function deterioration is also a condition which is controlled and treated by internists.

\section{b) Secondary health care - internists}

The following is part of secondary health care:

- The internist is obliged to inform every patient with deteriorating renal function who wants to get pregnant about all the risks from the pregnancy for the mother as well as for the baby;

- S/he is also obliged, in consultation with a gynaecologist, to choose the best form of contraception which will not contain hormones, especially in patients with hypertension;

- In the case of pregnancy, to refer the patient to nephrologist;

- To give the patient's data to the nephrologist in which data about renal function based on the-24-hour creatinine clearance, once every 6 or 12 months will be presented.

\section{c) Tertiary health care - University Nephrology Clinic}

The University Nephrology Clinic performs the following:

- Determines the extent of kidney damage and primary kidney disease, determines the possibility of pregnancy, i.e. indicates termination of the pregnancy together with the gynaecologist;

- A pregnant patient with deteriorating renal function which requires ending the pregnancy in spite of the explained risks, is followed regarding the renal disease and appropriate therapy is prescribed (in collaboration with gynaecologist);

- Issues protocol according to the literature about renal parenchymal disease and the possibility of pregnancy and terminating the pregnancy and delivers it to the internists;

- Treats with conservative and active treatment with dialysis any patient with acute kidney disease from any cause during pregnancy and after delivery;

- Controls and treats patients with pregnancyderived hypertension in collaboration with the gynaecologist. This concerns preexisting hypertension, as well as pregnancy-derived hypertension of the preeclampsia type;

- Determines the type of treatment, dosage and period when the antihypertensive therapy will 
start after prior diagnosis of the type, classification group and other parameters for hypertension. Determines when the therapy will be stopped before conception if it is contraindicated during the pregnancy.

\section{NEPHROLITIASIS}

\section{a) General notions}

In this part the procedures for early detection, prevention and treatment of renal lithiasis will be described. Team collaboration (urologist, endocrinologist) in treating these patients is also emphasized.

\section{b) Primary health care}

In this part patients with an accidental discovery of lithiasis, familial predisposition to lithiasis and patients with clinical symptoms of renal colic and painful lumbar syndrome will be discussed. The following diagnostic procedures are performed:

- Urine sample, blood urea, creatinine;

- Urine culture.

The treatment is symptomatic.

\section{c) Secondary health care - internists}

- Accepting patients with persistent renal colic, multiple daily residues, renal colic along with vomiting and loss of fluids and with fever.

- Diagnostic methods are:

- Ultrasound;

- Blood and urine analysis (urea, creatinine, uric acid, proteins, $\mathrm{Ca}$, phosphorus, alkaline phosphatase, calciuria, oxaluria, cistinuria, sediment, cyanide nitroprussid test);

- Urine culture;

- Good patient case history;

- Contrast urography.

- The treatment includes definite resolving of the colic, substitution with fluids and symptomatic therapy.

\section{d) Tertiary health care - University Nephrology Clinic}

The University Nephrology Clinic performs the following:

- Evaluates the etiology and pathogenesis of the nephrolithiasis;

- Evaluates activities of the nephrolithiasis:

- RTG;

- Ultrasound;
- Metabolic components.

- Determines the chemical structure of the stone;

- Determines the type of the stone:

- Oxalate;

- Oxalate-phosphate;

- Phosphate;

- Oxalate-urate;

- Urate;

- Magnesium - ammonium - phosphate.

- Analyses the renal function;

- Analyses the obstructive elements (anomalies and predisposing factors);

- Creates a programme for primary, secondary and tertiary prophylaxis and prevention of recidivism, as well as prevention of the progression of renal failure;

- Creates a protocol on concerning choosing active therapy;

- Analyses nephrocalcinosis.

\section{INTENSIVE NEPHROLOGICAL TREATMENT AND CARE}

\section{a) General notions}

This part includes care for patients with acute, life-threatening conditions as a result of global kidney damage. Based on the condition of these patients, and the urgency of the diagnostic and therapeutic procedures, it is necessary to transport the patients as soon as possible to the University Nephrology Clinic.

\section{b) Primary health care}

- Anamnesis for acute problems with urination (decreased urination, difficult urinating and stop in urine);

- Data about global renal failure (nausea and vomiting, change in the bodily hydration, skin and mucosa paleness, muscular spasm, skin and mucosa bleeding, changes in the breathing: acidotic, polypnea, etc);

- Laboratory data for increased blood urea, creatinine and potassium.

\section{c) Secondary health care - internists}

Anamnestic and objective data about acute, life-threatening conditions as a result of global kidney damage:

- Decompensated manifested acidosis;

- Weakness in the extremities (hyperkaliemia); 
- Damaged bowel transit (constipation: hyperand/or hypokalemia); diarrhoea : hyponatremia, $\mathrm{pH}$-derived bowel distension;

- Damaged muscular excitability (hyper/hypokalemia) type spasm, muscular contractures, laryngospasm, extended or shortened $\mathrm{S} \mathrm{T}$ interval in the EKG;

- Haemorrhagic shock as part of global renal failure (most frequent digestive bleeding, massive epistaxis, rarely massive haematuria);

- Hypertensive crisis with or without left heart failure, i.e. hypertensive encephalopathy in persons with global renal failure, i.e. renal hypertension;

- Malignant arterial hypertension in aggressive antihypertensive treatment phase (hypotension with shock, thromboembolism);

- Decreased consciousness following renal metabolic disorder, i.e. cerebral circulatory damage (uraemia, acidosis, encephalopathy).

Laboratory and other procedures in secondary health care:

- Blood count, haematocrit, platelets, serum proteinogram, sodium, potassium, calcium, chloride, phosphate, urea, creatinine, glycaemia, urine (specific mass, proteins, $\mathrm{pH}$, sediment), urine culture, proteinuria/24 hours, alkaline reserve (CO2, total bicarbonates).

Discriminating acute from chronic renal failure:

- Ultrasound: quality of the parenchyma, kidney size and symmetry).

Differentiating organ from functional acute renal failure (ARF):

- Mannitol test (100 $\mathrm{ml} \mathrm{20 \% )}$ by measuring hourly urine. If more than $45 \mathrm{ml} /$ hour urine is gained, hydration and conservative treatment is advised. The result is in favour of inorganic renal failure;

- Furosemide test $(250 \mathrm{mg}$ furosemide in 250 $\mathrm{ml}$ saline in one hour). If more than $60 \mathrm{ml} / \mathrm{h}$ urine is gained ARF can be excluded.

General notion:

Every patient with a life-threatening condition as a result of acute renal failure with or without urine stoppage and after exclusion of inorganic ARF (absence of urine with normal arterial tension) should be sent to the University Nephrology Clinic as soon as possible.

\section{d) Tertiary health care - University Nephrology Clinic (intensive care department)}

The University Nephrology Clinic in its intensive care treats patients who have lifethreatening conditions:

- Patients with acute oligoanuria caused by: sepsis, haemorrhagic syndrome with shock, following polytrauma and operations complicated with acidosis, hyperkalemia, fluid-natriuretic disorders and disorders of the haemostasis;

- Patients with chronic, i.e. acute, worsening chronic renal failure;

- Patients with a transplanted kidney who have life-threatening conditions (graft failure, with acute metabolic disorder: dyskalemia, hypertensive crisis, severe sepsis);

- The clinic performs the most modern diagnostic procedures for quick detection of the condition, and adequate and early treatment;

- The clinic takes part in joint treatment of patients from other clinics with complications with affected kidney function and need active and highly-differentiated nephrological protection (dialysis, metabolic reanimation);

- Provides efficient and continuous monitoring of vital functions in these patients;

- Treats all complications with dialysis, vascular access and creates modalities.

\section{CHRONIC KIDNEY DISEASE}

\section{a) General notion}

Patients are treated in primary, secondary and tertiary health care, with maximal coordination among the three levels.

\section{b) Primary health care (predialysis stages of CKD)}

Primary health care physicians are responsible for early diagnosis of chronic kidney disease (CKD). For that purpose, they should screen risk groups for developing CKD by measuring serum creatinine, the presence of proteins in the urine, and other urinary markers and morphological kidney abnormalities:

- in those with hypertension;

- in those with diabetes mellitus;

- in those with heart diseases (atherosclerotic coronary, cerebral or peripheral vascular disease, as well as heart failure);

- in those with anaemia of an unknown cause; 
- In those with familiar anamnesis for terminal renal failure or on dialysis;

- In those who have a systemic disease which may cause chronic kidney damage;

- Along with urinary markers and morphological renal abnormalities, the physicians should know how to determine kidney function by measuring calculated creatinine clearance (CCC) with the Cockroft-Gault formula:

Female $\mathrm{CCC}=1.044 \times(140$-age $) \times$ weight /serum creatinine;

Male $\mathrm{CCC}=1.23 \times(140$-age $) \times$ weight $/$ serum creatinine.

- Endogen creatinine clearance from $24 \mathrm{~h}$ urine;

- Creatinine clearance ( MDRD);

- If serum clearance is above reference, the kidney function may be halved, and that is the reason why the creatinine clearance should be measured with these formulas;

- If CCC is less than $60 \mathrm{ml} / \mathrm{min}$ the patient should be transferred to a nephrologist.

Primary care physicians should know how to recognize the signs of acute renal failure, i.e. acute worsening of chronic kidney failure, by recognizing the causes which have led to them.

Prerenal causes:

- Haemorrhage, dehydration (prolonged hypotension);

- Shock ( cardiogenic, septic);

- Kidney damage from nephrotoxic drugs (non steroid anti-inflammatory drugs, except paracetamol, aminoglycosides, trimetoprime, penicillin, antituberculostatics, penicillamine, gold salts, alopurinol, lithium, citotoxic drugs, cyclosporine), as well as iodine and other radio-contrast materials;

- Renal causes: acute glomerulonephritis, acute pyelonephritis, rhabdomiolisis;

- Post renal causes: benign prostatic hypertrophy, pelvic tumours.

If reversible causes for acute renal failure are present, after their correction, serum creatinine or CCC should be repeated after one month.

If the $\mathrm{CCC}$ is less than $60 \mathrm{ml} / \mathrm{min}$ and acute or acute worsening of chronic kidney disease which does not improve after correction of the adverse causes is present - the patient should be transferred to a nephrologist.

The primary health care physician should try to determine the eventual cause of the CKD:
- Obstructive (prostate hypertrophy, calculosis, tumours, haematuria, ultrasound and other radiographic techniques for morphological evaluation);

- Hypertensive glomerolosclerosis (hypertension);

- Glomerulopathies, system diseases which lead to kidney damage (proteinuria $>1 \mathrm{~g} /$ day, referral to a nephrologist for kidney biopsy);

- Urinary infections (haematuria, leucocituria);

- Diabetic nephropathy (diabetes and proteinuria $>1 \mathrm{~g}$ /day with a tendency towards nephrotic range).

Even if the cause of the CKD is known, or is just an assumption, the patient is referred to a nephrologist for precise diagnosis of the primary kidney disease.

Follow-up of a patient with confirmed CKD is in collaboration with a nephrologist.

- Frequencies of controls depend on the primary kidney disease, i.e. the level of progression;

- Measuring CCC should be done from once every two months to twice a year;

- Patients with first, second and eventually third stage CKD (according to K/DOQI) can be followed by a primary health care physician in collaboration with a nephrologist (guidelines for therapy and additional diagnostic procedures);

- Patients with fourth and fifth stages of CKD should be treated by nephrologists.

Therapy which can be prescribed in primary health care

- Treatment with ACE inhibitors which are indicated for decreasing proteinuria and slowing the progression of the kidney disease or angiotensin receptor blockers (serum creatinine, potassium and sodium should be measured before and 2-4 weeks after the start of the therapy);

- Calcium carbonate, when serum calcium is below the threshold or serum phosphorus exceeds the threshold $(\mathrm{Ca} \times \mathrm{P}$ product should not exceed 5.5);

- Advice for liquid ingestion (2-3 litres/24 h);

- Advice for reduced salt ingestion (3-5 g/24 h). If necessary, loop diuretic;

- Advice for reduced ingestion of potassium (increased risk of hyperkalemia when ACE inhibitors and angiotensin receptor blockers, 
potassium sparing diuretics or non-steroid inflammatory drugs, and especially their combination, are used).

\section{Treatments prescribed by nephrolo-} gists or in hospital:

- Dietary advice for reduced ingestion of proteins and phosphates $(0.6-0.8 \mathrm{~g} / \mathrm{kg} /$ day $)$. Reduced ingestion of dairy products when serum creatinine is above $150 \mu \mathrm{mol} / \mathrm{l}$. For secondary parathyroidism control, vitamin D therapy is used. It is necessary to refer the patient to a nephrologist (monitoring of serum PTH (parathyroid hormone) and acidobase balance) before the therapy with alphacalcidol $0.25 \mu \mathrm{g} / 24 \mathrm{~h}$ is started, as well as for parathormone inhibition and the need for therapy with calcimimetics;

- For adynamic bone disease control and decreasing or changing the phosphate binder it is necessary to refer the patients to a nephrologist;

- Referral to a nephrologist is necessary for evaluating vascular calcifications (US of the carotid and femoral arteries, radiogram of the abdominal aorta in profile and standard of the pelvis);

- For acidosis treatment (serum bicarbonate below $18 \mathrm{mmol} / 1$ or below $15 \mathrm{mmol} / \mathrm{l}$ ) the patient should be referred to a nephrologist (calcium carbonate 2-3 g/day);

- Referral to a nephrologist is necessary for treatment of hyperlipidaemia, use of statins and fibrates;

- For anaemia correction, therapy with exogenous erythropoietin is necessary, indicated by a nephrologist, and then control in collaboration with primary health care;

- Referral to a nephrologist is necessary for assessment of the bodily reserves in iron (transferrine saturation index, ferritin);

- Iron supplementation is important, it is given orally or intravenously. Referral to a nephrologist is necessary for intravenous iron;

- In the case of infection, deterioration of the kidney function is possible. It should be treated with antibiotics by a physician in primary health care, correction of the dehydration and hypertension which may accompany infection, and in a case of severe infection, referral to hospital.

- Treatments prescribed in hospital:

- Erythropoetin, parenteral iron;
- Vitamin D, paracalcitol, cinacalcet, sevelamer;

- Pharmacotherapy of hyperlipidemia;

- Dietary advice.

\section{c) Secondary health care - internists}

At this level, the following is performed:

- The recording and registration of every newly-discovered patient with renal failure, and further referral of the patient to the University Nephrology Clinic. The referral is with an adequate medical record;

- Performing classical or sequential or other types of haemodialysis, after approval from the clinic;

- Dialysis centres at this level should have appropriate personnel, i.e. specialist internists, who have completed a six month course in dialysis, and passed a theoretical and a practical exam in front of three examiners, for which they gain a certificate. Nurses with higher education or with high school diplomas and more than three years experience, who have taken a six month course in the clinic, passed a theoretical and a practical exam in front of a commission of nurse with higher education, a technical engineer and a professor, will gain a certificate;

- The centre is run by a subspecialist nephrologist, or a specialist internist until the title nephrologist is gained;

- When renal failure is worsened, some centres may insert femoral or subclavian catheters after prior agreement from the clinic, as temporary vascular access for dialysis;

- Implement new techniques for dialysis after prior agreement from the clinic after prior supervision that they fulfil assumptions that it will be successful, efficient and rational;

- Create preemptive AV fistula and perform correction of AV complications after prior supervision and approval of the clinic;

- Test dialysis adequacy and patient rehabilitation according to the principles given by the clinic;

- Report deaths of any patients included in register for chronic dialysis programme, or on transplantation waiting list on form given by the clinic;

- The centres are obliged to send all complicated cases to the clinic first. The request for treatment and examination outside the clinic, with explanation, is sent for evaluation; 
- Worsened renal failure which requires urgent dialysis is treated as acute renal failure and is treated at the University Nephrology Clinic. Uncomplicated cases can be treated in the centres, which insert temporary vascular access. The responsibility for the outcome is taken by the centre;

- Treats and controls patients on peritoneal dialysis which is indicated and started at the University Nephrology Clinic;

- Performs therapy and other measures indicated from the clinic, making sure they are not altered in patients with chronic renal failure with or without dialysis or transplanted;

- All centres which perform dialysis are obliged to implement preventive measures regarding $\mathrm{HBV}, \mathrm{HCV}$ and HIV infection in personnel according to the principles from the clinic.

\section{d) Tertiary health care - University Nephrology Clinic}

- Takes care of patients with chronic renal failure - compensated, through a special programme which includes hygiene, dietetic regime and prevention of renal failure progression;

- Indicates start of chronic dialysis programme for every patient with terminal renal failure, determines the frequency, dosage, type, therapy and other measures. Inserts temporary and permanent access for dialysis;

- Performs the following dialysis methods:

- Continual ambulatory peritoneal dialysis;

- Chronic ambulatory haemofiltration;

- Chronic ambulatory haemodiafiltration (biofiltration);

- Chronic ultrashort high efficacy dialysis;

- Chronic ambulatory-tailored dialysis;

- Standard haemodialysis and bicarbonate dialysis;

- Plasmapheresis;

- Haemadsorption;

- Continual arteriovenous haemofiltration;

- Acute peritoneal dialysis;

- Haemodialysis with modalities.

- Provides temporary and permanent vascular access for haemodialysis:

- Plans the type, location and duration of the vascular access. This depends on a detailed clinical assessment and other parameters (primary kidney disease, degree of renal failure, anaemia, metabolic and electrolytic status of the patient). Some paraclinical tests are necessary prior to creating vascular access: echocardiography, angiography, haemostasis, Doppler of the blood vessels;

- Performs all standard procedures for providing primary and secondary vascular access, i.e. temporary and permanent (central venous catheters, native arterioveinous fistula - AVF, biological and synthetic vascular grafts - VG);

- Tests functionality of the vascular access, failure, stenosis, suspected AVF or VG thrombosis, hyperkinetic AVF or VG and its effect on the cardiovascular system. Evaluation of the function is done using dynamic tests - intravenous digital subtraction angiography (i.v. DSA), echo colour Doppler, spiral CT (computed tomography), angiography, magnet resonance, etc. Evaluation and retaining the function of central venous catheters (CVC) (temporary and permanent) regarding thrombosis and infection (malfunction). CVC malfunction is evaluated with contrast radiological methods, microbiological analysis (swabs, haemocultures, catheter tips), echo Doppler, etc.;

- Treats complications in all types of vascular accesses;

- Doctrinal stance on planning, performing and treating complications.

- Implements new dialysis techniques and transfers knowledge and, when conditions are applicable, determines who can implement them;

- Runs central records of all patients on dialysis in the Republic;

- Gives criteria for dialysis adequacy and rehabilitation;

- Supervises the work in the centres for dialysis for transferring new knowledge and tests if the protocol is being carried out, at least once a year. Following every visit, a form in is made in triplicate;

- The clinic is responsible for education (physicians, nurses, technicians). Education is carried out in the form of courses and seminars. For each education course a certificate is given. Once a year the clinic organizes a seminar for testing knowledge. Materials from the seminars have a doctrinal standing until the following seminar. The finance for the seminar is provided by the Ministry of Health and Education; 
- The clinic is responsible for the education of subspecialists - nephrologists;

- Determines the need and possibilities for home dialysis. Educates the patients and others who will perform it.;

- The clinic is the determining factor and advisory body for procurement of equipment, and other resources in this area.

\section{KIDNEY TRANSPLANTATION}

\section{a) General notion}

All activities in this domain of nephrological care are done by the University Nephrology Clinic. With special agreement, some investigations for assessment of adequacy for kidney transplantation can be performed in the dialysis centres for.

\section{b) Primary health care}

\section{c) Secondary health care - internists and dialysis centres}

- Assessment of adequacy for kidney transplantation starts at this level. It comprises:

- HLA typisation of every patient on chronic dialysis;

- Conducting transfusiological protocol following recommendations from the University Nephrology Clinic;

- Assessment of the skeletal system with radiography of the hands, feet and long bones, laboratory findings of calcium, phosphates and alkaline phosphatase;

- Assessment of the HBV, HCV and hepatic status;

- ECG and teleradiography of the heart.

- The procedure of living kidney transplantation concerning activities regarding the donor:

- Blood group and $\mathrm{Rh}$ factor;

- Basic laboratory;

- Teleradiography and ECG;

- Nephroangiography;

- Kidney scan with assessment of separated glomerular filtration rate (GRF);

- Procedure for performing transplantation. When activities of major urgency are performed, the dialysis centre must organize transport of the potential recipient to the University Clinic with all the documentation;
- Procedure concerning complications with the graft and patient. Every condition concerning renal function of the graft or connected with a deterioration of the health of patients with a transplanted kidney is sent immediately to the Clinic;

- Dialisys centres are obliged to conduct all therapeutic measures in patients with a transplanted kidney. They must not in any way change the immunosuppressive therapy without prior consultation with the Clinic;

- Dialysis centres are obliged to remain in constant contact with the University Nephrology Clinic for all information regarding the condition of the potential kidney recipients who are on the waiting list.

\section{d) Tertiary health care - University Nephrology Clinic}

- Procedure for assessment of adequacy for kidney transplantation. Includes the following activities:

- Determining the primary disease with histological assessment when possible;

- Determining every pathological condition in various systems and organs in the patient which can present a temporary or permanent contraindication for the operation;

- Following the cytotoxic antibodies and creating a serological database for every patient who is a candidate for kidney transplantation;

- Conducting a complete track of internistic and nephrological conditions following the immune status;

- Maintaining constant contact with the dialysis centres;

- Procedure concerning living donor transplantation. This comprises tests which will exclude every pathological condition and will guarantee maximal safety for the donor, and tests which will confirm the immunological compatibility between the donor and the recipient;

- Procedure after specific protocol for preparation of the pair for ABO incompatible kidney transplantation (different blood groups);

- Procedure for kidney transplantation. The University Nephrology Clinic accepts all candidates for kidney transplantation, after a previous call, in cases of an available cadaveric kidney. The call is made by the nephrological team after previous testing of the 
HLA system, cross-matching with the sera from the previously prepared sera database and received agreement for organ explantation.

The patient is prepared for urgent operative procedure according to accepted protocols.

The procedure for living kidney transplantation is arranged and is not urgent.

- The University Nephrology Clinic accepts transplanted patients at all times after a prior announcement. In severe cases they are joined by a doctor or nurse. Later the clinic performs highly differential tests for the diagnosis and therapy of all possible complications in the graft as well as in the patient, col-

\section{Резиме}

\section{ПРОТОКОЛ ЗА ИЗВЕДУВАњЕ \\ НЕФРОЛОШКА ДЕЈНОСТ \\ ВО РЕПУБЛИКА МАКЕДОНИЈА}

Момир Поленаковиќ́ ${ }^{1,2}$, Стевка Богдановска' Кочо Чакалароски ${ }^{1}$, Соња Џикова ${ }^{1}$, Ѓ орѓи Масин ${ }^{1}$, Јелка Масин-Спасовска ${ }^{\mathbf{1}}$, Ангел Ончевски ${ }^{1}$, Весна Герасимовска', Гоце Спасовски ${ }^{1}$, Ристо Гроздановски ${ }^{1}$, Оливера Стојчева-Танева ${ }^{1}$, Ладислава Грчевска ${ }^{1}$, Александар Шиколе ${ }^{1}$, Петар Дејанов ${ }^{1}$, Лилјана Тозија ${ }^{1}$, Катица Зафировска ${ }^{1}$, Нинослав Ивановски ${ }^{1}$, Љубица Лозанче ${ }^{1}$, Владимир Пушевски ${ }^{1}$

1 Клиника за нефрологија, Медицински факултет, Скопје, Универзитет „Св. Кирил и Методиј“, Скопје, Р. Македонија

${ }^{2}$ Македонска академија на науките и уметностите, Скопје, Р. Македонија

Брзиот развој на нефрологијата во светот, особено во втората половина на 20 век, бараше протокол (упатства) за нефролошка активност за сите нивоа на здравствена заштита, на лека- laborating with other highly differential structures of the Medical Faculty;

- The University Nephrology Clinic, through its subspecialist kidney transplantation clinic, follows all transplanted patients and prepares protocols. All patients with a transplanted kidney must be followed through a subspecialistic clinic.

\section{REFERENCES}

1. Macedonian Medical Review, 1994; Supplement 14: 397-406. рите и специјалистите. Меѓународното здружение за нефрологија, Европската ренална асоцијација и други национални здруженија создадоа свој протокол (упатства) за нефролошка дејност. Македонското здружение за нефрологија, дијализа, трансплантација и вештачки органи (МЗНДТВО) го објави Првиот протокол за изведување нефролошка дејност во Република Македонија на Првиот конгрес на МЗНДТВО, што се одржа во Охрид во 1993 година, и тоа беше објавено во Македонски медицински преглед во 1994 година; суплемент 14: 397-406. Ажурираниот Протокол за вршење нефролошка дејност во Република Македонија беше објавен на Четвртиот конгрес на МЗНДТВО, што се одржа во Охрид во 2012 година, и е презентиран во овој текст.

Клучни зборови: нефролошки протокол, упатства, национално здружение, Македонско здружение за нефрологија, дијализа, трансплантација и вештачки органи (МЗНДТВО). 